\title{
Correction to: Multinational corporations and tax havens: evidence from country-by-country reporting
}

\author{
Javier Garcia-Bernardo ${ }^{1}$. Petr Janský ${ }^{2}$ (D) Thomas Tørsløv ${ }^{3}$
}

Published online: 16 March 2021

(C) Springer Science+Business Media, LLC, part of Springer Nature 2021

\section{Correction to: International Tax and Public Finance https://doi.org/10.1007/s10797-020-09639-w}

The original version of this article contained a mistake in the co-author name "Javier Garcia-Bernando". The correct co-author name should read as "Javier Garcia-Bernardo". The original article has been corrected.

Publisher's Note Springer Nature remains neutral with regard to jurisdictional claims in published maps and institutional affiliations.

The original article can be found online at https://doi.org/10.1007/s10797-020-09639-w.

Petr Janský

petr.jansky@fsv.cuni.cz

Javier Garcia-Bernardo

javier.garcia.bernardo@gmail.com

Thomas Tørsløv

thomas.torslov@econ.ku.d

1 University of Amsterdam, Amsterdam, Netherlands

2 Institute of Economic Studies, Faculty of Social Sciences, Charles University, Prague, Czech Republic

3 University of Copenhagen, Copenhagen, Denmark 